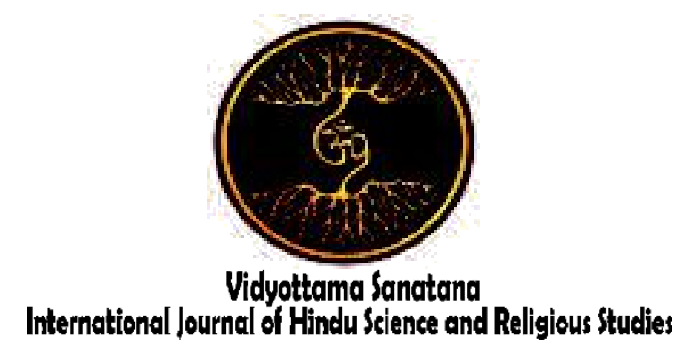

Vol. 2 No. 1 May 2018

\title{
Bayon Temple In The Development Of Budhisme In Cambodia
}

By:

Bopha Kunthea

Pannasastra University of Cambodia

E-mail: $\underline{b \_k u n t h e a @ g m a i l . c o m ~}$

\begin{abstract}
Cambodia is experiencing tremendous tourism developments. Many choices of tourist attractions that can be selected by tourists. Each tourist attraction provides interesting offers for tourists who visit. The existence of temples in Cambodia is the main attraction for tourists, so many temples start to become a tourist spot. Bayon Temple is one of the tourist attractions visited by tourists. Utilization of Bayon Temple as a tourist visit is a result of tourism development. These developments affect the social and cultural life of Buddhists in Cambodia.
\end{abstract}

Keywords: Bayon temple, development of Budhisme

\section{Introduction}

The existence of temple in Cambodia is not spared by the influence of the world globalization. The temple that was originally only as a place of worship began to change towards the tourism so that became a tourist attraction. The existence of the Bayon Temple located in Angkor Archeological Park Siem Reap, Cambodia is also inseparable from the cultural tourism that develops today.
This temple located in the center of the Jayavarman's capital city, Angkor Thom, and was built around the end of $12^{\text {th }}$ century. As a part of the Khmer Empire's architectural wealth, the Bayon Temple is the last government's temple dedicated to the Buddha, which is built on Angkor's heyday. This temple has undergone changes and additions in some parts, adapted to the religious teachings of each successor king. 
Bayon Temple also describes the earth and as the center of the imaginative axis that connects between mountains and the sea. Without this axis, life in Jayavarman is not in balance, which makes it impossible to maintain the order of hierarchy. The hierarchy is intended to overcome the conflict of disunity and be realized through the implementation of the ceremony held at the Bayon Temple. The relationship between mountains, land, and the sea as symbolized by those temples, and once again as shown in the Bayon Temple is very important. Without this temple which is being the axis, agriculture is unlikely to take place (Nordholt, 2006: 96). It makes the Bayon Temple has its own charm that can not be found elsewhere.

Many theorized that the 216 statue of a giant face was actually a representation of the Avalokiteśvara's face, the Bodhisattva that embodied the compassion of all Buddhas. There is also a theory declare that Jayavarman VII as a Buddhist identifies himself with the Buddha and that Bodhisattva. Bayon Temple which is now well-known as a tourist attraction has opened up many opportunities for cultural activities for the local community.

The life of Buddhists at Angkor Archeological Park Siem Reap is filled with religious activities performed by Buddhists. The inhabitants of Angkor Archeological Park Siem Reap are Buddhist people. The relationship between Buddhists and nonBuddhist s going well, without any conflict. Economic, information, and cultural globalization has offered a variety of transparency and freedom (Chankrisna, 2011: 131). Globalization stimulates the minds of people to be more open, skilled, and observant in reading opportunities. This is become a challenge of society for the future.
The challenge faced by Cambodian humans in this globalization era is very complex. This could be seen from the high struggling between local and global values that enters all the joints of human life. The influence of globalization could not be rejected because it is a sign of the new age that brings about changes in social and cultural aspects of society (Arun, 2011: 1). In line with Arun's opinion, the arrival of the new age brought about changes in aspects of social and cultural life of the people who originally functioned the Temple of Bayon as a place of worship then turned into multifunctional. That is, beside that as a place of worship, temple area is also used as tourist attractions, recreational rides and places to showcase the art of Cambodian tourism performances new packaging. This shows that the life of the community in the past which is still in the traditional order has been affected by modern culture. Thus, the buddhist should have a great stronghold in establishing belief through the understanding of Buddhism.

Thinking of God means that the people should known God in His reality, as the essence known as the Sang Tathagata (Chantha, 1999: 5). Likewise with the people of the Bayon Temple's complex, people should know the God worshiped at the Bayon Temple. The existence of the Bayon Temple as a place of worship of Sang Gotama began to gain influence and cause changes in line with the development of tourism so that the impact on the religious life of Buddhists.

\section{Result and Discussion}

\subsection{The Meaning of Buddhism At Bayon Temple}

Awareness is a key element of meaningful action. The meaning of Buddha's 
teaching in the Bayon Temple could be seen through the consciousness of the people in believing the existence of God. Buddhists at Angkor Archeological Park Siem Reap believe that the Buddha at the Bayon Temple is a manifestation of God. The most basic Buddhist doctrine is known as the Four Noble Truths, four facts which are regarded as authentic by the higher-conscious beings.

1. First Noble Truth: True Issues. Although there is a lot of excitement to have in life, every creature-from the smallest insects, to the homeless, to the billionaires-faces trouble. Between birth and death, we are getting old and then sick, or our loved ones die. We face failure and disappointment, not getting what we want, or seeing what we do not want.

2. Second Noble Truth: The True Cause of Problems. The problems arise from the causes and circumstances, but the Buddha says that the real reason is our ignorance of reality: how do we envision the impossible ways of confronting ourselves and all people and everything else.

3. The Third Noble Truth: Halting of Problems. The Buddha saw that it is actually possible for us to get rid of all human problems so that we will not experience them again, by quell the cause: our own folly.

4. The Fourth Noble Truth: The True Path of mind. Problems stop when we get rid of ignorance, by understanding reality rightly. We did it by realizing that everyone is connected and interdependent. On this basis we develop love and compassion for all beings equally. Once we get rid of the confusion about how we and other creatures exist, we are able to act beneficially for ourselves and other beings.

Once built in the 12th century, the Bayon Temple was made with three layers of stone fence. If sorted from the outermost layer to the deepest layer and seen from the air, then the Bayon Temple is like a lotus bud about to bloom. Each fence is decorated by the Apsara relief and the sculpted smiling face that faces all sides. Avalokitesvara's faces 216 and spread over 49 towers. Now, some of the stone statues choose to stand firm, others were forced to surrender by time.

The main purpose of the Buddhist faithenhancing effort is to achieve happiness, and inner welfare. The hope is that there is a synergy between behavior and belief in Buddhism, both to the single God and to others, also to all of His creations in this universe (Samkhann, 2008: 4). As a creature that has a human predicate is a creature who has reason, who has the power of thought, ingenuity, intelligence, ability, memory, feelings and consciousness. However, because of sin, lobha and moha (hatred, greed and ignorance) then the person who should uphold the value of humanity is just the opposite, cruel, sadistic, fierce; likes to harm, torture, harm, kill; no love, compassion, sympathy and no policy and no human nature at all.

Actions occur massively so transparent, but actually, attitudes and actions that reflect the absence of human values encountered almost in daily life. Bullying or intimidation from the great to the small, strong to the weak, the majority to the minority; robbery, plunder, persecution, torture, murder and others are the 
reflection of the loss of human nature and this could be encountered in daily life.

The rebirth into this world is called punarbhawa, the birth circle. Rebirth condition is depends on deeds. If a man carries good karma (good deeds), then born with a happiness, able-bodied, and successful person. Conversely, when human brings bad karma, will born as a suffering person. This rebirth is an opportunity to improve our quality of life (Samnang, 1991: 12). Angkor Thom society is made up of several elements or groups of life, so to meet their needs is should be in accordance with the needs of his group life. There are four kinds of food, namely:

1. Kabalimkahara (food in the form or form of matter or thing). This food is needed by the physical body to sustain and meet its needs so that the body grows healthy, strong and not easily damaged.

2. Phassahara (food in the form of sense objects). This food is needed to cultivate the senses, so that it becomes strong, observant and tough. (For example, a child who has not been able to read and write, but because it is trained to recognize the alphabet by continuously he can finally read and write, which means their senses are getting stronger).

3. Vibbanahara (food in consciousness object form). This food is needed to develop awareness so that it becomes strong, intelligent and conscientious to lead to perfect consciousness. But it should be understood that the object food of consciousness required is positive objects. For example, the object of consciousness in meditation is always directed toward a clean consciousness free from bad intention, hatred, angry, annoyed, emotional, selfish, arrogant and always developing love and affection (metta-karuna), patience (khanti) spirit (viriya), and right understanding (samma-ditthi).

4. Mano-sacetanahara (food in the form of will). This food is also needed to encourage the realization of a desired goal. For example, someone should have the willingness to work in order to gain success; a person must have the will to change attitudes and mindsets so as not to get caught in the wrong view and achieve a peaceful and happy life, there is the word pearl that reads "Success is not depend on the size of knowledge and skill, but success is depend on how great the willingness." This suggests that the importance of such food is for the sake of success, attainment to perfect freedom because that need is a supporters, a movers and a motivator.

It is clear that what is meant by food, not just necessities that are required by the body but completely, that is; food in the form of matter and food in the form of truth (Dhamma) which is the inner need. By fulfilling the complete necessities of life, the spiritual morals which are the veins of human nature will grow and develop.

\subsection{Preservation of Arts and Culture}

Art and culture should be preserved in the midst of globalization era's development. The goal is to preserve the art, and the culture 
inherited by the ancestors. Art and culture are attractively packed by the community at Angkor Archeological Park Siem Reap which is featured as a form of cultural capital.

Intangible (created by God) and tangible (created by human) capital as the basis for tourism development has positioned culture as capital, so tourism is one form of cultural industry that utilizes cultural practices in a production system. Positioning culture as capital in the culture industry encourages the change of cultural meaning, in this case the culture is aligned with other resources such as natural resources, and human resources. Further cultural capital undergoes commoditization process, and monetization in a process of production, distribution, and consumption (Samay, 2010: 22).

Cultural capital is a part of human capital or often called human resources (HR). In human capital besides cultural capital, also contained intellectual capital, social capital, and spiritual capital. The essence of cultural capital is creativity, and aesthetics. The essence of intellectual capital is knowledge, experience, skill, and innovation ability. The main essence of social capital are values, and norms that's are believed together, while the essence of social spiritual capital is faith, and spirit. Nowadays, the role of those all capital is very important as production factor that can generate income, and wealth because society work based on quality of population and human resources which is having values, and norms that are believed together (Samay, 2010: 23).

In effort of analysis, or in order to anticipate future developments, it is necessary to strengthen the vision that creativity is a means to preserve the culture, even the traditional culture, and not a threat to cultural preservation. With creativity, someone can make various efforts: by glorifying inherited cultural and create of new things that are perceived as relevant to present needs (Chhay, 2007: 38).

Community's creativity in the form of cultural practices that attract tourists, so that is the capital of tourism or tourism assets. Thus, cultural capital contains a potency, and could be developed into an attractive tourist attractions and complementary with travel motives. Cultural capital carried out by the Cambodian government in collaboration with communities in Angkor Archeological Park Siem Reap developed the Bayon Temple as a cultural tourism spot. The existence of the Bayon Temple began to receive special attention by all parties in tourism industry. In addition, the Cambodian government also developed a tourist attraction that was arranged in a dinner. The dinner activities initiated by the Cambodian government, and working with community, especially the Angkor Archeological Park community can create a new atmosphere in the development of cultural tourism.

Tourism activities usually held in the Bayon Temple is directly managed by the government in cooperation with the community. It has a positive economic impact on society (Sokhon, 2010: 58-59). The other positive impact that can be generated is the fostering of intercultural relationship. Intercultural relationships are important nowadays in adding useful information.

Intercultural relationship is one of powerful tool to innovate. Innovation occurs when a number of foreign conventions relate to tradition. The inventor serves as a "bridge" or a connecting point between two different 
ways of life: the findings will attract the people who want to participate, and loosen the tight bonds that prevail in the culture of origin (Sanwawann, 2004: 5). Change or development is usually only initiated by people who have power: chieftain or king.

The continuity of a tradition is depends on the continuous refreshment or innovation of its supporters in developing the uniqueness of individuals, details, habits, internal perceptions, and externals (Sanwawann, 2004: 3). This dinner activity is a new innovation that brings a change within the Angkor Archeological Park Siem Reap community. This innovation is featured in the Bayon Temple by combining local culture owned by the community at Angkor Archeological Park Siem Reap as a form of art preservation, and culture. Thus, the existence of the existing community in Angkor Archeological Park Siem Reap participate actively in presenting local culture owned.

\subsection{Bayon Temple and Welfare Improvement}

It is undeniable that tourism has contributed greatly to the rapid pace of Cambodian economic growth nowadays, and more so in the growing physical development in that island (Picard, 2006: 143). Visitation at the Bayon temple is happening daily.

Many tourists come to visit personally by bringing personal vehicles, as well as using the services of existing travel agencies. The existence of the Bayon Temple as a cultural tourism destination greatly impacted the increase in income for the community along with the increasing number of tourists visiting. The existence of the Bayon temple provides improved welfare for the Angkor Archeological Park Siem Reap community.

In accordance with the sustainable paradigm of sustainable tourism, the community is given the greatest opportunity to participate in the development of tourism so that the people get the optimal benefits, and fair. Community development measures include resource allocation, institutional strengthening, and empowerment of human resources or community empowerment (Hieng, 2007: 58).

The opening of employment at the Bayon Temple has absorbed the workforce that comes from Angkor Archeological Park Siem Reap community members. This means having a positive impact on people's welfare to reduce the number of unemployed in Angkor Archeological Park Siem Reap. The people who work in the Bayon Temple are gets a benefit greatly because the workplace is adjacent to the location of the house where they lives.

The meaning of prosperity that is expected in the development of cultural tourism, could not be analyzed from the economic side only, but also should be looked from the side of intertwining harmonious life in society, whether harmonious with the environment, fellow, or harmonious with supernatural powers that the existence are believed.

\section{Conclusion}

The Bayon temple is located in the center of Jayavarman's capital, Angkor Thom, and was built around the end of the 12th and early 13th centuries. The Bayon Temple is the last government's temple dedicated to the Buddha, built in Angkor's heyday. The temple gives a picture of the majesty of the Buddha's 
teachings. All processes or events are Anicca or always changing, unsatisfactory or Dukkha, Anatta or no person of this consciousness, mind, feeling, perception, and body. The mind arises because there is a support, there is contact, there is an awareness that depends on the factors exist in mind. When a greedy person sees something and is interested, then firstly, that person will be amazed, appreciative, eager to have. But if the person is wise, so doesn't have the nature of greed, then humans do not intend to have. Therefore it is advisable to look at something, think naturally. When doing Vipassana practice, self-awareness and wisdom will arise. Wisdom is the knowledge of the Dhamma, if it is understood actually about Anicca, Dukkha, and Anatta, then man can avoid the earthly attachment

\section{References}

Alkire, William H. (1972). Concepts of Order in Southeast Asia and Micronesia." Com-parative Studies in Society and History 14(4): 484-493

Apter, David E. (1963) Political Religion in the New Nations." In Old Societies and New States, ed. Clia ord Geertz, 57-104. Glencoe, IL: Free Press.

Armstrong, John P. (1964). Sihanouk Speaks: Cambodia's Chief of State Explains His Con troversial Policies. New York: Walker

Bond, George D. 1996. “A. T. Ariyaratne and the Sarvodaya Shramadana Movement in Sri Lanka." In Engaged Buddhism: Buddhist Liberation Movements in Asia, ed. Christopher S. Queen and Sallie B. King, 121-146. Albany: State University of New York Press.
Bou Norin, trans. 1957. Celebration of the 2,500th Anniversary of the Buddha's Parinir-vana. Phnom Penh: Padumavati Ràjavàrama Pagoda.

Boulbet, J., and B. Dagens. 1973. "Les sites archéologiques de la région du Bhnar Gùlen (Phnom Kulen)." Arts Asiatiques 27 (special issue).

Boulbet, Jean. 1970. "Kbal Spean: The Stream of a Thousand Lingas." Nokor Khmer (Jan- uary-March): 2-17.

Boyle, Kevin, and Juliet Sheen, eds. 1997. Freedom of Religion and Belief: A World Re-port. London and New York: Routledge.

Briggs, Lawrence Palmer. 1951. "The Syncretism of Religions in Southeast Asia, Espe- cially the Khmer Empire." Journal of the American Oriental Society 71:230-249.

Brocheux, Pierre. 1972. "Vietnamiens et minorités en Cochinchine pendant la période coloniale." Modern Asian Studies 6(4): 443-457.

Caldwell, Malcolm, and Lek Tan. 1973. Cambodia in the Southeast Asian War. New York and London: Monthly Review Press.

Carbonnel, J.-P. 1973. "Le stupa Cambodgien actuel." Arts Asiatiques 26:225-242. Carney, Timothy Michael. 1977. Communist Party Power in Kampuchea (Cambodia):

Documents and Discussion. Data Paper no. 106. Ithaca, NY: Southeast Asia Program, Cornell University.

DeVoss, David. 1980. "Buddhism under the Red Flag." Time, November 17, 62-63. Dhaninivat Kromamun Bidyalabh Bridhyakorn, H. H. Prince. 1963. The 
Royal Palaces. Bangkok: Fine Arts Department.

Ebihara, May. 1966. "Interrelations between Buddhism and Social Systems in Cambo- dian Peasant Culture." In Anthropological Studies in Theravada Buddhism, ed. Man- ning Nash, Cultural Report Series no. 13, 175196. New Haven, CT: Yale Univer- sity Southeast Asia Series.

Pachow, W. 1958. "The Voyage of Buddhist Missions to South-east Asia and the Far East." Journal of the Greater India Society 17(1-2): 1-22.

Panditha, Vincent. 1973. "Buddhism during the Polonnaruva Period." In The Polon- naruva Period, 3rd ed., ed. S. D. Saparamadu, 127-145. Dehiwala, Sri Lanka:Tisara Prakasakayo.

Rao, U. (2017). Understanding Buddhism through Pali in India and Thailand. Vidyottama Sanatana: International Journal of Hindu Science and Religious Studies, 1(2), 115-121.

San Sarin. 1975. "Les textes liturgiques fondamentaux $\mathrm{du}$ bouddhisme Cambodgien actuel."PhDthesis, École Pratique des Hautes Études, Section Sciences Religieuses, Paris.
Sudarsana, I. K. (2017). Interpretation Meaning of Ngaben for Krama Dadia Arya Kubontubuh Tirtha Sari Ulakan Village Karangasem District (Hindu Religious Education Perspective). Vidyottama Sanatana: International Journal of Hindu Science and Religious Studies, 1(1), 1-13.

Sudarsana, I. K. (2017). THE IMPORTANCE OF MORALS TEACHING IN SHAPING THE STUDENTS'CHARACTERS IN SCHOOL. DAFIS PROCEEDING, 306-315.

Sudarsana, I. K. (2016). DEVELOPMENT MODEL OF PASRAMAN KILAT LEARNING TO IMPROVE THE SPIRITUAL VALUES OF HINDU YOUTH. Jurnal Ilmiah Peuradeun, 4(2), 217-230.

Sripakdee, P. P. (2017). The Role Of Buddhist Ethics And Communication In The Contemporary World Crisis. Vidyottama Sanatana: International Journal of Hindu Science and Religious Studies, 1(2), 155-159.

Weggel, Oskar. 1984. "Buddhismus und Sozialismus: Die Völker Indochinas auf der Suche nach der verlorenen Identität." Südostasien Aktuell 3(1): 47-65. 